A. K. Ботапева [A. K. Botasheva]

И. А. Герейханова [I. A. Gereikhanova]

В. Н. Панин [V. N. Panin]

УДК 32.019 .51

\title{
ПОЛИТИЧЕСКИЙ РR В СФЕРЕ МЕЖДУНАРОДНЫХ ОТНОШЕНИЙ
}

\section{POLITICAL PR IN THE SPHERE OF INTERNATIONAL RELATIONS}

Пятигорский государственный университет, Россия, г. Пятигорск/ Pyatigorsk State University, Russia, Pyatigorsk, e-mail: ab-ww@mail.ru

\begin{abstract}
Аинотация. Возросиее влияние информачионных технологий приеело к тому, что вопрос построения не только эффективных, но и системных коммуникаций стал актуален, поскольку порядок международных отноиений нуждается $в$ более предсказуемьх, более опкрытых взаимодействиях межгосударственного характера, в том числе и в сфере полити-
\end{abstract} ческого PR.

Ключевые слова: политический PR, политические коммуникации, международные отношения, информационное общество.

Abstract. The increased influence of information technology has led to the fact that the issue of building not only effective, but also systemic communications has become urgent, as far as the order of international relations needs more predictable, more open interactions of an interstate nature, including in the field of political PR.

Key words: political PR, political communications, international relations, information society.

Introduction. Today, political PR in the field of international relations has been little studied, which actualizes the research of this problem. The researchers' attention was focused only on certain applied aspects of PR and, first of all, in the context of considering the formation of the image of nation-states in the international arena. We also has not succeeded in developing an integrated theoretical concept of political PR in the field of international relations, since the phenomenon is quite complex and requires further atention of scientists.

Methods of analysis. Most often, political PR is considered in the applied aspect, which, of course, causes a refusing from conceptual evaluations of PR. The study is maintained by using approaches based, first, on the theory of stereotypes of W. Lippman [18] (which made it possible to consider political PR in the context of imposing stereotypes, images, patterns); secondly, on the theory of "party support" by B. Birelson [21] and P. Lazarsfeld [23] (they focus on the effectiveness of political PR according to the country); thirdly, the theory of "political discourse" by S. Black [2] (the focus is on "case studies"); and the theory of "public opinion" (the focus is on methods of forming public opinion through information resources) - D. Butler [1] and D. Thompson [26] and others. The method of comparative analysis made it possible to compare the educational programs of several countries, internal integrativity (integrity) which is aimed at the effective organization of the work of political PR in the field of international relations. At the same time, the problem of isolating the actual concrete methods of political PR in the field of international relations has faded into the background and, accordingly, is not reflected as a methodological setting.

The main part of the study. The political PR in the international sphere was deeply studied by Frank Jeffkins and Daniel Yadin, the authors of the textbook "Public Relations", which was later translated into Russian. The researchers identify an "international PR" with international marketing, and write that the rules of international marketing can be applied in international PR. The author's suggestion that "many of the problems of communication with foreign markets can be resolved using the services provided in the UK" seems disputable [17, 204-205; 25, 3-4].

The basic concept of our research is in understanding of international PR presented by E.V. Kedyarova, Dennis L. Wilcox, Glen T. Cameron and Brian H. Reber, who were more accurate in scientific developments. Thus, domestic researchers interpret political $\mathrm{PR}$ in the field of international relations as "a form of political communication oriented to constant contacts between political actors and the public" [10, 2], while Dennis L. Wilcox, Glen T. Cameron and Brian H. Reber use the term "International public relations" and define it as "planned and organized efforts of a company, organization or government aimed at establishing mutually beneficial relations with the public of other countries" [22].

A statement of a systemic understanding of political PR in the field of international relations suggests that the concepts: "advertising and public relations in the politics of international relations", "state PR in the international arena", "state PR in the foreign market" or "international PR" are synonymous to our understanding of term "political PR in the field of international relations" and mean a form of political communication between the subjects of international politics and the public.

In this sense, it is legitimate to talk about the following key target users of information coming in line with public relations in the field of international relations, which are:

1. first, The UN and UNESCO, as they are sources and subjects of international law. 
2. UN specialized agencies operating under the auspices of the General Assembly and / or Economic and Social Council (ECOSOC): [19]

- The World Bank is a multilateral lending institution, consisting of five closely interconnected institutions uniting members of the International Monetary Fund, whose common goal is to promote the economic and social development of the countries of the world (mainly developing and post-socialist) through financial assistance to advanced economies. The headquarters of all five institutes are located in Washington. The World Bank Group includes: [12]

a) IDA (International Development Association - 169 member countries, including Russia). The goal is to provide poor countries with special incentives and interest-free loans at the expense of donor countries. Russia in the status of a donor [3];

b) IFC (International Financial Corporation - 170 member countries, including Russia). The goal is to encourage private entrepreneurship in developing countries and thus promote economic growth;

c) MAIG (International Agency for Investment Guarantees - 134 member countries, including Russia). The purpose of the organization is to facilitate the flow of investment in developing countries, the provision of guarantees;

d) ICSID (International Center for the Settlement of Investment Disputes - 119 member countries, including Russia). The organization's tasks include the provision of arbitration and other legal services to member countries, informing about investment legislation. The goal is to promote the growth of international investment;

e) IBRD (International Bank for Reconstruction and Development - 180 member countries, including Russia). The goal is to promote the growth of production and international trade in member countries by providing soft loans and long-term financing of projects and programs in that direction.

- IMF (International Monetary Fund - 181 member countries, including Russia). The purpose of the organization is to promote the growth of international trade, to regulate the stability of exchange rates, the provision of shortand medium-term loans (only to state bodies, in tranches, the receipt of which is strictly linked to the fulfillment by the state of jointly defined obligations). Only from 1992 to 1999, the IMF provided Russia with loans worth more than \$ 20 billion. Headquarters - in Washington [6, 77-105];

- UNCTAD (United Nations Conference on Trade and Development - 186 member countries, including Russia). Objectives - international cooperation is aimed at promoting the development of international trade. The focus is on accelerating economic growth in developing countries. Headquarters - in Geneva;

- UNIDO (United Nations Industrial Development Organization - 166 member countries, including Russia). Main goals: industrialization of African countries, promoting industrial growth at the national, regional and global levels, reconstruction of industry in post-socialist countries. Headquarters in Vienna;

- The WTO (replaced by the GATT in 1995 by the World Trade Organization - 159 member countries, including Russia (the Republic of China is a partially recognized state) [16]. The purpose of the WTO is to liberalize international trade, regulate tariff and trade policies, subsidize exports, standardization and certification of goods, setting duties, import licensing, etc. Headquarters in Geneva;

- FAO (food and agricultural organization - 169 member countries plus the European Union). In collaboration with FAO, the World Food Program is operating - the leading international organization for the distribution of food aid. The goal is to end hunger in developing countries;

- IFAD (International Fund for Agricultural Development - 158 member countries, which are conditionally divided into three categories: a) donor countries, which include 22 developed and 12 developing countries - oil exporters and 124 developing countries. The goal is poverty alleviation, increased food production), headquarters in Rome.

3. INGOs (International Non-Governmental Organizations; English Non-governmental organizations), such as: [12]

- Ecumenical Council of Churches;

- Red Cross,

- OPEC (Organization of Petroleum Exporting Countries);

- Pugwash movement (organizations of scientists);

- FIFA (sports organizations);

- Amnesty International (legal organizations, etc.

4. IGOs (International Governmental Organizations):

- OSCE (Organization for Security and Co-operation in Europe), brings together 56 states of Europe, North America and Central Asia. The purpose of the organization is to promote comprehensive security in the militarypolitical sphere, humanitarian, economic and environmental dimension;

- NATO (North Atlantic Treaty Organization - North Atlantic Treaty Organization);

- EU (European Union);

- ASEAN (The Association of Southeast Asian Nations, Association of Southeast Asian Nations). Participating countries: Thailand, Philippines, Cambodia, Laos and Myanmar, Brunei Darussalam, Singapore, Malaysia, Indonesia, Vietnam, East Timor, Papua New Guinea. The goal is mutually beneficial cooperation;

- BRICS (informal interstate association). Composition of BRICS: Russian Federation, Federative Republic of Brazil, China, Republic of India, Republic of South Africa. The BRIC acronym was proposed in 2001 by Jim O'Neill, head of the global economic research department at Goldman Sachs, an American financial and investment company, to designate the four economies of the world with the fastest growing GDPs - Brazil, Russia, India and China. In connec- 
tion with joining BRIC South Africa in December 2010, the group began to bear the name BRICS. July 25-27, 2018, the tenth anniversary BRICS summit was held in Johannesburg (South Africa);

- SCO (Shanghai Cooperation Organization. Member countries: China, Russia, Kazakhstan, Kyrgyzstan, Tajikistan, Uzbekistan, India, Pakistan). The objectives of the SCO: strengthening stability and security in the participating countries;

- CIS (Community of Independent States);

- OIC (international Islamic organization), etc.

According to Russian scientists, the list of subjects of advertising and public relations in the politics of international relations also includes: [8,281]

- governments and elites of foreign countries;

- international public organizations;

- foreign investors and shareholders;

- an expert community whose professional interests affect this state (financial and industry analysts, political scientists, sociologists, economists, etc.);

- representatives of the world community, including citizens, potential and real tourists, as well as the general population of foreign countries.

But this list is far from complete, since "international organizations are one of the notable subjects of international relations only from the second half of the XX century. At the beginning of the XX century there were about twenty intergovernmental and about two hundred non-governmental international organizations, then at the beginning of the XXI century there were about three hundred and more than forty thousand, respectively"[13, 24].

We have already noted that the object of attention of researchers of political PR in the field of international relations is often certain applied aspects of PR and, first of all, in the context of considering the formation of the image of nation-states in the international arena. Researchers suggest that in the corresponding segment in relation to a particular state, image formation in three different dimensions is possible: [8, 281]

1) at the civil level, based on economic or political values,

2) at a specialized level, which covers specialized or professional interests,

$3)$ at the ordinary level: covers the implementation of cognitive, leisure and everyman interest.

S. Anholt notes that the basic criteria for the formation of an international image of the state is a synthesis of "brand management, public diplomacy, trade, investment, tourism and export promotion, competitiveness in the global world, is something that is already starting to pay dividends for many countries," cities and regions - both rich and poor "[20,36]. Speaking about the actual political criteria for communication in the field of international relations, T. Moylanen and S. Rainisto discuss the country's image in terms of commercial marketing: "There are three important concepts ... that are associated with brands: identity, image and communication" $[24,7]$.

In our opinion, the external image of the state is formed through internationally-visible components of the following nature:

- political;

- environmental;

- social and legal;

- cultural;

- military strategic;

- sports;

- health care;

- living standards of the population;

- scientific achievements;

- human rights and freedoms;

- objectivity of published statistical indicators;

- the activities of political elites;

- international ratings;

- image of the head of state, etc.

We agree with Yu.G. Zheglova, that an effective image of the state can be the result of the synergistic effect of many vectors [7, 10-12]. And, as O.N. Zhiltsova, I.M. Sinyaeva and D.A. Zhiltsov, suppose "external state PR is designed to provide powerful information support" $[8,282]$ to all disasters that influence the image of the state.

International initiatives of the state are also of great importance for political PR in the field of international relations. So, the next 74th session of the UN General Assembly, which took place on September 24-30 of this year in New York, went down in history by the adoption of a Russian resolution on arms control during the Session. In this sense, it is legitimate to say that the Russian initiative gained almost all votes. Three states: Palau, Ukraine and Georgia abstained. The remaining 179 states, including the United States, voted unanimously, supporting Russia's resolution "on strengthening and developing the system of treaties and agreements on arms control, disarmament and nonproliferation" [5]. 
At the same time, Western society in accordance with such criteria as the lack of transparency in the conduct of domestic business, the activities of the office of officials, the lack of open databases in the social environment, etc. suggested the sites of Russian campaigns the worst in Europe. [9]. Meanwhile, even according with formal logic, within the framework of the existing paradigm of Russian communication, the Russian side influences world public opinion extremely inefficiently. Created in 2005 on budget money, the Russian-language television channel Russia Today, with a budget of \$ 30 million per year, has little impact on public opinion around the world. Effective news agencies today are the USIA (United States News Agency), the Federal Press and Information Office (FRG), and the British Council, together with the Central Bureau of Information. As a result, there is a negative image of Russia as a state with an aggressive foreign policy, implicated in doping scandals, with a lack of transparency in the economy and a corrupt society.

In the modern information society, the role of political PR has greatly increased, therefore, the system of international public relations is becoming more integrated. So, we should expect that the priority in the information impact on the objects of political PR in the field of international relations is given to international media channels. This means that the communication space of the international information society is formed through the basic mechanisms of communication with the public at the global level. As the former US Secretary of State Z. Brzezinski rightly remarked, today "means of communication represent the third generation of means of world domination" $[14,17]$. These are diplomatic services, mass media, mass means of communication, representative offices abroad, organizations of cultural cooperation, international activities of transnational corporations [15, 177-178].

We aslo should take into account the dichotomy of the development of the modern global community, where sometimes mutually exclusive trends of globalization and glocalization are observed (glocalization is the term of the English sociologist Roland Robertson, which means the processes of decentralization, the so-called "new regionalism"). On the one hand, globalization demonstrates the desire not only of countries but also of regions to act as full-fledged subjects of international relations. On the other hand, glocalization "is realized, as a rule, from below, and not from above, it includes, in addition to economic issues, environmental and safety problems, and many social and cultural institutions along with states act as its actors" [11,111]. Consequently, informational work in the field of modern Public Relations implies the development of civil society institutions and responsibility in finding the best ways to integrate countries included in regional agreements into global processes (glocalization / new regionalism, which is now radically different from the protectionist orientation of old regionalism). In addition, when creating an international PR campaign, it is necessary to take into account social, economic, political and cultural differences in all spheres of life of different societies, since each national culture is distinguished by its originality, a set of its own characteristics. And this is not only about different types of political and economic systems, but also about values, beliefs, stereotypes or language differences.

The recognition of the importance of political PR in the field of international relations determines the actions of most states in the context of building a coherent system of educational programs in master's and doctoral programs. So, according to British standards, several models of master's programs in PR function at the School of Business of the University of Manchester Metropolitan - Manchester Metropolitan University, MMU, UK. The course of the program "Public Relations" lasts one year and ends with the defense of the dissertation. Various programs in the higher education system (mixed type, practical or academic) offer European standards. In the framework of higher education, masters study PR for two years, which makes it possible to continue their studies in doctoral studies. As S.M. Vinogradova, G.S. Melnik and K.A. Pantserev note, "Among the specialized (PR, journalism, marketing, management) educational institutions in Germany, the most famous are, for example, DIPR (Deutsches Institut für Public Relations - German Institute of PR), Free University, Institute of Journalism and Communication in Berlin (Public Relations) ), as well as the Universität Leipzig, Institut für Kommunikations- und Medienwissenschaft (communication area, media relations) "[4, 148].

Focusing on building professional potential, Boston University (Boston University, USA) has gained solid experience in training a PR specialist in the international sphere. The university faculty pays close attention to theoretical knowledge and practical skills: the ability to be creative in solving PR tasks and think critically.

In this regard, it is worth noting that Russian universities "are also focused on training high-class specialists in public relations. The Diplomatic Academy of Foreign Affairs of the Russian Federation, Peoples' Friendship University of Russia (PFUR), Moscow State University (MSU), Moscow State Institute of International Relations (MGIMO), St. Petersburg State University "[4, 137] - these are not a complete list of Russian universities that contain educational programs that train specialists for government agencies in the field of external PR. The study of political PR as one of the instruments for influencing public opinion and in general as an instrument of foreign policy is admitted as paramount in this respect.

Our Pyatigorsk State University also achieves success in training of public relations practitioners. In the framework of the training of specialists in International Relations (skills profile - international security) and the training of Masters in Advertising and Public Relations (skills profile - public relations in international relations), specialists are trained to pursue a career in international security and international PR combined with studying two foreign languages.

According to S.M. Vinogradova, G.S. Melnik and K.A. Pantsereva, during the training, the following aspects should be important both for teachers and trainees: [4, 148]

- information support of special international events; 

events, etc.;

- the study of blogging, mobile marketing, flash mobs, conversion technologies, web presentation, offline the external public;

- the specifics of creating written and oral PR-texts in international public communication;

- newsmaking in the field of international relations;

- news agenda and work with an informational occasion based on modern media technologies;

- information management and spindoktoring;

- news management;

- media relations;

- global and local political image;

- the country's participation in global political, economic and socio-political processes, etc.

The findings of the study. A statement of a systematic understanding of political PR in the field of international relations suggests that the concepts: "advertising and public relations in the politics of international relations", "state PR in the international arena", "state PR in the foreign market" or "international PR" are synonymous with our understanding of "political PR in the field of international relations" and mean a form of political communication between the subjects of international politics and the public.

It can be concluded that a theoretical study of political PR in the field of international relations requires the use of methodological tools in the humanities, which can fully reflect the evolution of the international sphere of human life and the place of political PR in it. On the practical plane, the role of education in the training of international PR specialists has increased.

A systems approach demonstrates that a deeper understanding of the state role in formation of political PR is quite relevant. Consequently, Russia, with its huge geopolitical potential and political opportunities should dominate the international arena, demonstrating a holistic strategy in creation of the state's image, stable political and economic situation in the country, and the formation of civil society and the middle class.

\section{ЛИТЕРАТУРА}

1. Батлер Дж. Психика власти: теории суббъекции. Спб.: Алетейя, 2002. 168 с.

2. Блэк C. Public Relations. Что это такое? М.: Новости, 1990. 239 с.; Блэк С. PR: Международная практика. М.: Издательский дом «Довгань», 1997. 180 с.

3. Большая российская энциклопедия. [Электронный ресурc]. URL: https://bigenc.ru/economics/text/2198768 (дата обращения 29.02.2020)

4. Виноградова С.М., Мельник Г.С., Панцерев К.А. Медиаориентированный подход в подготовке специалистов по связям с общественностью в сфере международных отношений // Медиаобразование. 2017. №. 1. С. 132-148.

5. Генассамблея $\mathrm{OOH}$ приняла резолюцию России по контролю над вооружениями. [Электронный ресурс]. [Электронный ресурc]. URL: https://ria.ru/20191107/1560655599.html (дата обращения 02.02.2020)

6. Дегтерев Д.А. Политическое влияние в международной финансовой системе // Вестник международных организаций: образование, наука, новая экономика. 2016. Том 11. №. 4. С. 77-105.

7. Жеглова ІО.Г. Трудности имиджевой политики в интересах Российской Федерации // Общество, политика, экономика, право. 2018. №. 4. С. 10-12.

8. Жильцова О.ІІ. Связи с общественностью. М.: Издательство ЮОрайт, 2019. 337 с.

9. Исследование: российские корпоративные сайты - худпиие в Европе. [Электронный ресурc]. URL: https://www.newsru.com/russia/12nov2007/site.html (дата обращения 02.02.2020)

10. Кедярова Е.В. Политический пиар в современнй России: полезные свойства для органов государственной власти и местного самоуправления // Электронный научный журнал «ГосРег». 2016. № 3. С. 2. [Электронный ресурc]. URL: http://gosreg.amchs.ru/ (дата обращения 29.02.2020).

11. Кожевников II.І., Пашкевич Н..Л. Глокализация: концепции, характерные черты, практические аспекты // Вестник Северо-Восточного федерального университета им. М.К. Аммосова. 2005. Том 2. №. 3. С. 111-115.

12. Международные глобальные организации. [Электронный ресурc]. URL: https://zdamsam.ru/b41805.html (дата обращцения 29.02.2020)

13. Олейнов А.Г. Анализ международных отношений с позиций экономической теории // ВЕСТНИК МГИМО УІІИВЕРСИТЕТА. 2011. № 1 (16). С. 15-24.

14. См.: Пугачев В.П. Социальные трансформации в постсоветской России в свете стратегии глобального управления человечеством // Государственное управление. Электронный вестник. 2015. Выпуск № 53. С. 17. [Электронный pecypc]. URL: https://cyberleninka.ru/article/n/16426175 (дата обращения 01.02.2020)

15. Связи с общественностью как социальная инженерия / Под ред. В.А. Ачкасовой. СПб.: Речь, 2005. С. 177-178. 29.02.2020).

16. Список стран-членов BTO. [Электронный pecypc]. URL: http://www.rgwto.com/wto.asp?id=5223 (дата обращения

17. Фрэнк Джефкинс, Дэниэл Ядин. Паблик рилейшннз / Пер. с англ. под ред. Б.Л. Еремина. М.: Юнити-Дана, 2003. C. 204-205. [Электронный pecypc]. URL: http://univer.nuczu.edu.ua/ (дата обрапения: 17. 02.2020).

18. Уолтер Липпман. Общественное мнение. М.: Институт фонда «Общественное мнение», 2004. $384 \mathrm{c}$.

19. Устав Организации Объединенных Наций. [Электронный ресурc]. URL: http://www.un.org/ru/charter-unitednations/index.html (дата обращения: 17. 02.2020). 
20. Anholt S. Competitive Identity: The New Brand Management for Nations, Cities and Regions. N. Y., 2007. 160 p.

21. Berelson B. Content Analysis in Communication Research. Glencoe, Illinois: The Free Press, 1952. 220 p.

22. Dennis L. Wilcox, Glen T. Cameron, Bryan H. Reber. Public Relations: Strategies and Tactics (11th Edition). - Pearson Education, 2014. 598 p.

23. Lazarsfeld P. The people's choice. How the voter makes up his mind in a presidential campaign. N.Y.: Columbia University Press, 1944. 187 р. [Электронный ресурc]. URL: https://link.springer.com/ (дата обращения: 17. 02.2020)

24. Moilanen T., Rainisto S. How to Brand Nations, Cities and Destinations: A Planning Book for Place Branding. N. Y., 2009. $230 \mathrm{p}$.

25. Frank Jefkins. Public Relations. Pitman Publisging. London, 1992. 250 p.

$380 \mathrm{p}$.

26. Thompson J.B. Ideology and Modern Culture: Critical social theory in the era of mass communication. - Oxford, 1990.

\section{REFERENCES}

1. Batler Dzh. Psikhika vlasti: teorii subyektsii. Spb.: Aleteyya, 2002. $168 \mathrm{~s}$.

2. Blek S. Public Relations. Chto eto takoye? M.: Novosti, 1990. 239 s.; Blek S. PR: Mezhdunarodnaya praktika. M.: Izdatelsky dom «Dovgan», 1997. $180 \mathrm{~s}$.

3. Bolshaya rossiyskaya entsiklopediya. [Elektronny resurs]. URL: https://bigenc.ru/economics/text/2198768 (data obrashcheniya 29.02.2020).

4. Vinogradova S.M., Melnik G.S., Pantserev K.A. Mediaoriyentirovanny podkhod v podgotovke spetsialistov po svyazyam s obshchestvennostyu $v$ sfere mezhdunarodnykh otnosheny// Mediaobrazovaniye. 2017. №. 1. S. 132-148.

5. Genassambleya OON prinyala rezolyutsiyu Rossii po kontrolyu nad vooruzheniyami. [Elektronny resurs]. [Elektronny resurs]. URL: https://ria.ru/20191107/1560655599.html (data obrashcheniya 02.02.2020).

6. Degterev D.A. Politicheskoye vliyaniye v mezhdunarodnoy finansovoy sisteme // Vestnik mezhdunarodnykh organizatsy: obrazovaniye, nauka, novaya ekonomika. 2016. Tom 11. №. 4. S. 77-105.

7. Zheglova YU.G. Trudnosti imidzhevoy politiki v interesakh Rossiyskoy Federatsii // Obshchestvo, politika, ekonomika, pravo. 2018. №. 4. S. 10-12.

8. Zhiltsova O.N. Svyazi s obshchestvennostyu. M.: Izdatelstvo Yurayt, 2019. 337 s.

9. Issledovaniye: rossiyskiye korporativnyye sayty - khudshiye v Yevrope. [Elektronny resurs]. URL: https://www.newsru.com/russia/12nov2007/site.html (data obrashcheniya 02.02.2020).

10. Kedyarova Ye.V. Politichesky piar v sovremenny Rossii: poleznyye svoystva dlya organov gosudarstvennoy vlasti i mestnogo samoupravleniya // Elektronny nauchny zhurnal «GosReg». 2016. № 3. S. 2. [Elektronny resurs]. URL: http://gosreg.amchs.ru/ (data obrashcheniya 29.02.2020).

11. Kozhevnikov N.N., Pashkevich N.L. Glokalizatsiya: kontseptsii, kharakternyye cherty, prakticheskiye aspekty // Vestnik Severo-Vostochnogo federalnogo universiteta im. M.K. Ammosova. 2005. Tom 2. №. 3. S. 111-115.

12. Mezhdunarodnyye globalnyye organizatsii. [Elektronny resurs]. URL: https://zdamsam.ru/b41805.html (data obrashcheniya 29.02.2020).

13. Oleynov A.G. Analiz mezhdunarodnykh otnosheny s pozitsy ekonomicheskoy teorii // VESTNIK MGIMO UNTVERSITETA. 2011. № 1 (16). S. 15-24.

14. Sm.: Pugachev V.P. Sotsialnyye transformatsii v postsovetskoy Rossii v svete strategii globalnogo upravleniya chelovechestvom // Gosudarstvennoye upravleniye. Elektronny vestnik. 2015. Vypusk № 53. S. 17. [Elektronny resurs]. URL: https://cyberleninka.ru/article/n/16426175 (data obrashcheniya 01.02.2020).

15. Svyazi s obshchestvennostyu kak sotsialnaya inzheneriya / Pod red. V.A. Achkasovoy. SPb.: Rech, 2005. S. 177-178. 29.02.2020)

16. Spisok stran-chlenov VTO. [Elektronny resurs]. URL: http://www.rgwto.com/wto.asp?id=5223 (data obrashcheniya

17. Frenk Dzhefkins, Deniel Yadin. Pablik rileyshnz / Per. s angl. pod red. B.L. Yeremina. M.: Yuniti-Dana, 2003. S. 204205. [Elektronny resurs]. URL: http://univer.nuczu.edu.ua/ (data obrashcheniya: 17. 02.2020).

18. Uolter Lippman. Obshchestvennoye mneniye. M.: Institut fonda «Obshchestvennoye mneniye», 2004. $384 \mathrm{~s}$.

19. Ustav Organizatsii Obyedinennykh Natsy. [Elektronny resurs]. URL: http://www.un.org/ru/charter-unitednations/index.html (data obrashcheniya: 17. 02.2020).

20. Anholt S. Competitive Identity: The New Brand Management for Nations, Cities and Regions. N. Y., 2007. 160 p.

21. Berelson B. Content Analysis in Communication Research. - Glencoe, Illinois: The Free Press, 1952. 220 p.

22. Dennis L. Wilcox, Glen T. Cameron, Bryan H. Reber. Public Relations: Strategies and Tactics (11th Edition). Pearson Education, 2014. 598 p.

23. Lazarsfeld P. The people's choice. How the voter makes up his mind in a presidential campaign. N.Y.: Columbia University Press, 1944. 187 p. [Elektronny resurs]. URL: https://link.springer.com/ (data obrashcheniya: 17. 02.2020). 2009. $230 \mathrm{p}$

24. Moilanen T., Rainisto S. How to Brand Nations, Cities and Destinations: A Planning Book for Place Branding. N. Y.,

25. Frank Jefkins. Public Relations. Pitman Publisging. London, 1992. 250 p.

26. Thompson J.B. Ideology and Modern Sulture: Critical social theory in the era of mass communication. - Oxford, 1990.

$380 \mathrm{p}$.

OБ ABTOPAX | ABOUT AUTHORS

Боташева Асият Казиевна, доктор политических наук, доцент, профессор кафедры медиакоммуникаций, журналистики и связей с общественностью Пятигорского государственного университета; тел.: 89614833806; E-mail: ab-ww@mail.ru 
Botasheva Asiyat Kazievna, Doctor of Political Science, Associate Professor, Professor of the Department of Media Communications, Journalism and Public Relations of Pyatigorsk State University;

tel.: 89614833806; e-mail: ab-ww@mail.ru

Герейханова Ириша Александровна, кандидат политических паук, доцент, зав. кафедрой медиакоммуникаций, журналистики и связей с общественностью Пятигорского государственного университета; тел.: 89283734758; E-mail: maryluck@mail.ru

Gereikhanova Irina Aleksandrovna, Candidate of Political Science, Associate Professor, Head of the Department of Media Communications, Journalism and Public Relations of Pyatigorsk State University; tel.: 89283734758; e-mail: maryluck@mail.ru

Папиш Виктор Николаевич, доктор политических наук, профессор, зав. кафедрой международных отношений, политологии и мировой экономики Пятигорского государственного университета; тел.: 89282675773; E-mail: paninv1@yandex.ru

Panin Victor Nikolaevich, Doctor of Political Science, Professor, Head of the Department of International Relations, Political Science and World Economy, Pyatigorsk State University; tel.: 89282675773;

e-mail: paninv1@yandex.ru

Дата поступления в редакцию: 15.01.2020

После рецензирования: 13.02 .2020

Дата принятия к публикации: 03.03.2020 